\title{
NILAI ANAK, STIMULASI PSIKOSOSIAL, DAN PERKEMBANGAN KOGNITIF ANAK USIA 2-5 TAHUN PADA KELUARGA RAWAN PANGAN DI KABUPATEN BANJARNEGARA, JAWA TENGAH
}

\author{
Value of Child, Psychosocial Stimulation, and Cognitive Development of 2-5 Years Old \\ Children in Food Insecurity Areas at Banjarnegara District, \\ Central Java Province
}

\author{
DWI HASTUTII ${ }^{1 *}$, ALFIASARI $^{1}$, CHANDRIYANI $^{2}$ \\ ${ }^{1}$ Staf Pengajar Departemen IImu Keluarga dan Konsumen, Fakultas Ekologi Manusia, \\ Institut Pertanian Bogor, Jalan Lingkar Kampus IPB Dramaga, \\ Bogor 16680 \\ ${ }^{2}$ Departemen IImu Keluarga dan Konsumen, Fakultas Ekologi Manusia, Institut Pertanian \\ Bogor, Kampus Dramaga, Bogor 16680
}

\begin{abstract}
Optimal growth and development during early childhood will be able to describe a better future, especially for children between 2-5 years old. The aim of the study was to analyze value of child, psychosocial stimulation, and cognitive development of 2-5 years old children in food insecurity areas at district of Banjarnegara, Jawa Tengah Province. Two subdistrict which were Pejawaran and Punggelan were selected purposively. From each subdistrict, 3 villages were chosen for a total of 6 villages served as site of the study. From each villages, 50 families with its children aged 2-5 years were randomly selected, for a total of 300 families as respondents of this study. Result showed that average score of value of children was $81,2 \%$. It means that parents had high of perception and expectation to their children. Meanwhile, average score of psychosocial stimulation for 2-3 years old children was $49,8 \%$ and for 3-5 years old children was $57,4 \%$. The average score of cognitive development for 2-5 years old children was 50,6\%, which indicated that children still had low cognitive development. There was significant and possitive correlation between value of children and psychosocial stimulation. In line with this, increasing of psychosocial stimulation score was followed by increasing of child cognitive development score. Result showed that cognitive development was significantly and positively influenced by length of maternal education, length of child's participation on preschool education, family economic status, and psychosocial stimulation. On the other hand, increasing of age of children will be followed by decreasing score of cognitive development.
\end{abstract}

Key words: 2-5 years old children, cognitive development, psychosocial stimulation, value of children

\section{PENDAHULUAN}

Masa-masa yang rentan dari kehidupan seseorang berada pada lima tahun pertama dalam kehidupannya yang merupakan pondasi bagi perkembangan selanjutnya. Menurut Anwar (2002), apabila pada masa tersebut pertumbuhan dan perkembangan seorang anak berjalan secara optimal diharapkan pada masa dewasa akan tumbuh menjadi manusia yang berkualitas. Manusia yang berkualitas harus didukung oleh perkembangan kognitif yang baik. Menurut Webster (1993) dalam Hastuti (2006), kemampuan kognitif berhubungan dengan aktivitas intelektual seperti berpikir, menjelaskan, membayangkan, mempelajari kata, dan menggunakan bahasa. Optimalisasi perkembangan kognitif dipengaruhi oleh kematangan fisiologis, terutama pada masa balita (Dariyo 2007). Seorang anak akan dapat melakukan koordinasi gerakan tangan, kaki maupun kepala secara sadar setelah saraf-saraf maupun otot bagian organ telah berkembang secara memadai. Artinya bahwa perkembangan kognitif harus diiringi dengan kematangan fisiologis. 
Kemampuan kognitif merupakan salah satu dimensi dari perkembangan yang memiliki peran yang besar terhadap kecerdasan. Menurut Dariyo (2007) perkembangan kognitif tidak lepas dari fakor genetik dan lingkungan. Lingkungan keluarga merupakan salah satu lingkungan bagi anak untuk memperoleh stimulasi psikososial. Sununingsih (2006) membuktikan bahwa stimulasi psikososial mempengaruhi perkembangan kognitif.

Agar anak dapat tumbuh dengan optimal, diperlukan lingkungan yang kondusif. Orangtua memiliki peranan yang sangat penting dalam menciptakan lingkungan guna merangsang potensi yang dimiliki oleh anak (Dariyo 2007). Oleh karenanya, praktek pengasuhan yang optimal dari orangtua sangat diperlukan. Pengasuhan adalah proses membesarkan, memberikan perlindungan, memberikan perhatian, dan nilai untuk perkembangan anak dari sejak lahir hingga memasuki usia dewasa (Brooks 2001). Tugas pengasuhan ini umumnya diserahkan kepada ibu sebagai pengasuh yang utama dan ayah. Pengasuhan yang dilakukan oleh ibu didasarkan pada pengetahuan yang dimiliki ibu, namun pengetahuan dan keterampilan yang dimiliki oleh ibu seringkali kurang memadai. Salah satu faktor yang mempengaruhi adalah tingkat pendidikan ibu. Pendidikan ibu merupakan faktor yang berhubungan dengan pengetahuan ibu (Khomsan 2002). Apabila ibu memiliki pengetahuan yang tinggi maka akan lebih aktif dalam mencari informasi untuk meningkatkan pengetahuan dan keterampilan dalam pengasuhan anak. Cara pengasuhan yang dilakukan orangtua dalam keluarga erat kaitannya dengan persepsi orangtua terhadap nilai anak.

Tujuan dari penelitian ini adalah: (1) menganalisis hubungan nilai anak dengan stimulasi psikososial pada keluarga rawan pangan; (2) menganalisis hubungan stimulasi psikososial dengan perkembangan kognitif anak pada keluarga rawan pangan; dan (3) menganalisis faktor-faktor yang mempengaruhi perkembangan kognitif anak pada keluarga rawan pangan.

\section{METODE}

Desain, Lokasi, dan Waktu
Penelitian ini dilakukan secara
purposive di Kabupaten Banjarnegara, Provinsi Jawa Tengah. Penelitian ini merupakan salah satu bagian dari penelitian payung yang berjudul: "Household Food Security, Family Resource Allocation, and Its' Impact to Child Development of Family Living in Rural Food Insecure Area in Banjarnegara-Central Java Province, Indonesia". Pemilihan kabupaten dilakukan dengan pertimbangan bahwa wilayah tersebut merupakan salah satu daerah yang termasuk ke dalam wilayah rawan pangan berdasarkan peta kerawanan pangan Indonesia (Martianto et al. 2008). Waktu penelitian (persiapan, pengumpulan data, pengolahan dan analisis data, serta penulisan laporan) adalah sembilan bulan terhitung Desember 2008 hingga September 2009.

\section{Cara Pemilihan Contoh}

Penelitian ini mengambil dua kecamatan terpilih secara purposive dengan beberapa pertimbangan. Pertimbangannya antara lain bahwa wilayah tersebut termasuk kategori wilayah yang rawan pangan juga dikarenakan banyaknya jumlah penduduk miskin. Dari dua kecamatan terpilih yaitu Kecamatan Pejawaran (dataran tinggi) dan Kecamatan Pugelan (dataran rendah), selanjutnya ditentukan tiga desa di tiap kecamatan, dengan pertimbangan bahwa desa tersebut termasuk desa yang rawan pangan. Selain itu, pemilihan desa ditentukan dari hasil rekomendasi Puskesmas setempat mengenai keadaan balita. Dari masing-masing desa terpilih, diambil secara acak 50 keluarga sebagai contoh dengan pertimbangan mempunyai minimal satu anak balita. Total keseluruhan contoh berjumlah 300 keluarga.

\section{Jenis dan Cara Pengumpulan Data}

Data yang dikumpulkan dalam penelitian ini terdiri dari data primer dan data sekunder. Pengumpulan data primer melalui wawancara menggunakan kuesioner dan pengamatan langsung. Data primer yang dikumpulkan meliputi karakteristik keluarga, karakteristik anak, nilai anak, stimulasi psikososial, dan perkembangan kognitif anak. Data stimulasi psikososial dalam keluarga diperoleh dengan menggunakan instrumen HOME (Caldwell \& Bradley 1986), sedangkan perkembangan kognitif anak diperoleh dengan menggunakan instrumen dari Departemen Pendidikan Nasional yang dimodifikasi. Data sekunder berupa jumlah balita diperoleh dari puskesmas, sedangkan data keadaan umum lokasi penelitian dan 
data demografi penduduk diperoleh dari pemerintah dan instansi setempat.

\section{Pengolahan dan Analisis Data}

Pengolahan data meliputi editing, coding, scoring, entrying, cleaning, serta analyzing dengan menggunakan program komputer Microsoft Excel dan SPSS for Windows. Data dianalisis secara deskriptif dan statistik inferensia. Analisis korelasi dilakukan untuk melihat hubungan antar variabel yang diteliti, sedangkan untuk melihat faktor-faktor yang mempengaruhi perkembangan kognitif dilakukan uji regresi.

\section{HASIL DAN PEMBAHASAN}

\section{Karakteristik Keluarga}

Dari seluruh contoh, sebanyak 156 kepala keluarga bekerja sebagai petani $(52,9 \%)$ dan 52 kepala keluarga sebagai buruh tani $(17,6 \%)$. Sementara itu, sebanyak 137 ibu contoh tidak bekerja $(45,7 \%)$ dan 98 ibu contoh bekerja sebagai petani $(32,7 \%)$.

Jumlah anggota keluarga contoh berkisar antara 3 sampai 12 orang dengan rata-rata 5 orang. Lebih dari separuh keluarga contoh merupakan keluarga kecil $(59,3 \%)$ dengan jumlah anggota keluarga $\leq 4$ orang.

Umur kepala keluarga berkisar antara 20 hingga 60 tahun dengan rata-rata berusia 35 tahun. Sebagian besar kepala keluarga berumur antara 21-40 tahun (81,4\%). Sementara rata-rata umur ibu contoh adalah 30 tahun dengan kisaran umur 20 hingga 60 tahun. Sementara itu, pendidikan keluarga contoh masih amat rendah karena sebagian besar pendidikan ayah dan ibu keluarga contoh hanya sampai tingkat sekolah dasar (60,3\% pada ayah dan $62 \%$ pada ibu).

\section{Pengeluaran per Kapita Keluarga}

Penghitungan pengeluaran per kapita menunjukkan bahwa keluarga memiliki pengeluaran rata-rata sebesar Rp 87.186,00 per bulan, lebih rendah dibandingkan dengan standar garis kemiskinan Kabupaten Banjarnegara tahun 2008 yaitu sebesar Rp 146.531,00 per bulan.

Keluarga mengalokasikan sebesar 49,4\% untuk memenuhi kebutuhan pangannya. Hal ini menunjukkan bahwa keluarga contoh pada umumnya masih lebih menekankan pada kebutuhan pangan dan kurang memperhatikan kebutuhan nonpangan, khususnya kebutuhan yang dapat meningkatkan kualitas sumberdaya manusia dalam keluarganya.

\section{Karakteristik Anak}

Usia anak contoh pada penelitian ini berusia antara 2-5 tahun dengan rata-rata usia anak 3,4 tahun. Berdasarkan jenis kelamin, sebanyak $55 \%$ anak contoh berjenis kelamin perempuan dan sisanya berjenis kelamin laki-laki. Kondisi tersebut hampir sama di kedua kecamatan.

Berdasarkan partisipasi pendidikan prasekolah anak, hanya sedikit contoh mengikuti pendidikan prasekolah (14,3\%). Fenomena ini menggambarkan masih jauh tingkat partisipasi kasar level pendidikan anak usia dini di kedua kecamatan dari tingkat partisipasi kasar level pendidikan anak usia dini nasional tahun 2008 (50,5\%). Secara umum, jenis pendidikan yang diikuti lebih banyak pendidikan program PAUD nonformal $(7,3 \%)$ daripada pendidikan TK $(4,3 \%)$ maupun TPA $(2,7 \%)$. Rata-rata lama mengikuti pendidikan prasekolah menunjukkan bahwa lebih dari separuh contoh $(51,2 \%)$ telah mengikuti pendidikan selama satu bulan.

\section{Nilai Anak}

Joshi dan Clean (1997) dalam Hernawati (2002) menyebutkan bahwa nilai anak merupakan persepsi dan harapan orangtua terhadap anak berdasarkan potensi yang dimiliki. Anak mempunyai nilai yang sangat penting dalam kehidupan seseorang atau suatu keluarga bahkan bila dibandingkan dengan nilai harta kekayaan. Nilai anak bagi orangtua dalam kehidupan sehari-hari dapat diketahui dari kondisi adanya kenyataan bahwa anak menjadi tempat mencurahkan kasih sayang dan sumber kebahagiaan keluarga (nilai psikologis). Disamping itu, anak merupakan tempat mensosialisasikan nilai-nilai (nilai sosial) dan juga menjadi tempat orangtua menggantungkan harapan (nilai ekonomi) baik di masa sekarang maupun di masa depan.

Berdasarkan Tabel 1, rata-rata pencapaian skor nilai anak lebih besar pada nilai ekonomi $(95,2 \%)$, yang kemudian diikuti 
Tabel 1. Rata-rata pencapaian skor nilai anak contoh

\begin{tabular}{lccc}
\hline \multirow{2}{*}{ Nilai Anak } & \multicolumn{3}{c}{ Rata-rata \pm SD } \\
\cline { 2 - 4 } & Pejawaran & Punggelan & Total \\
\hline Nilai Psikologis & $63,4 \pm 23,6$ & $71,0 \pm 21,8$ & $67,2 \pm 23,0$ \\
Nilai Ekonomi & $92,3 \pm 15,6$ & $98,0 \pm 8,5$ & $95,2 \pm 12,8$ \\
Nilai Sosial & $82,8 \pm 16,9$ & $91,1 \pm 13,2$ & $86,9 \pm 15,7$ \\
Nilai Anak Total & $77,6 \pm 14,7$ & $84,9 \pm 11,1$ & $81,2 \pm 13,5$ \\
\hline
\end{tabular}

oleh nilai sosial $(86,9 \%)$. Secara keseluruhan nilai anak, harapan, dan persepsi orangtua kepada anak mempunyai skor yang lebih tinggi di Kecamatan Punggelan.

\section{Stimulasi Psikososial}

Pengukuran stimulasi psikososial dilakukan dengan alat bantu HOME Inventory, dimana stimulasi psikososial dibagi berdasarkan kategori usia. Untuk usia 2-3 tahun, pengukuran stimulasi psikososial dilihat dari tanggap rasa dan kata, penerimaan terhadap perilaku anak, pengorganisasian lingkungan anak, keterlibatan ibu terhadap anak, dan kesempatan variasi asuhan anak.

Berdasarkan rata-rata persentase skor, persentase skor terbesar dari enam subskala HOME untuk anak usia 2-3 tahun adalah keterlibatan ibu terhadap anak yaitu 61,6\%. Sementara itu, rata-rata persentase skor terendah adalah penyediaan mainan untuk anak yaitu 16,6\% (Tabel 2).

Tabel 2. Sebaran anak contoh menurut rata-rata pencapaian skor subskala HOME Inventory usia 2-3 tahun

\begin{tabular}{|c|c|}
\hline Subskala & Rata-rata \pm SD \\
\hline Tanggap rasa dan kata & $59,5 \pm 24,8$ \\
\hline Penerimaan terhadap perilaku anak & $60,7 \pm 16,9$ \\
\hline Pengorganisasian lingkungan anak & $59,0 \pm 17,8$ \\
\hline Penyediaan mainan untuk anak & $16,6 \pm 19,1$ \\
\hline Keterlibatan ibu terhadap anak & $61,6 \pm 21,3$ \\
\hline Kesempatan variasi asuhan anak & $36,6 \pm 21,9$ \\
\hline$\%$ Rata-rata keseluruhan subskala & $49,8 \pm 14,3$ \\
\hline
\end{tabular}

Hal ini berarti sebagian besar ibu sudah mampu melaksanakan subskala keterlibatan ibu dengan baik yaitu dengan memberikan pengawasan secara langsung atau sambil bekerja dan juga berbicara kepada anak selama mengerjakan pekerjaan. Rendahnya subskala penyediaan mainan menandakan masih kurangnya ketersediaan mainan yang dapat merangsang perkembangan kematangan jiwa anak. Hal ini juga kemungkinan terjadi karena keterbatasan ekonomi dan juga pengetahuan untuk dapat menyediakan mainan yang dapat menjadi media belajar untuk merangsang perkembangannya.
Sementara itu, stimulasi psikososial anak usia 3-5 tahun dilihat dari stimulasi belajar, stimulasi bahasa, lingkungan fisik, kehangatan dan penerimaan, stimulasi akademik, modelling, variasi stimulasi kepada anak dan hukuman. Persentase terbesar dalam pencapaian skor dari delapan subskala HOME untuk usia 3-5 tahun adalah skor subskala stimulasi bahasa sebesar $87,3 \%$. Hal ini berarti bahwa sebagian besar ibu sudah mampu melaksanakan subskala ini dengan baik yaitu dengan mengajari anak mengenal nama-nama binatang, belajar huruf alfabet, mengucapkan salam, terima kasih, memberi kesempatan anak, dan tanggapan ibu terhadap anak. Disamping itu, pencapaian skor terkecil yaitu terdapat pada subskala stimulasi belajar sebesar $23 \%$ (Tabel 3). Hal ini menunjukkan bahwa ibu masih kurang dalam memberikan stimulasi belajar kepada anaknya. Misalnya, kurang dalam memberikan alat bantu yang dapat mendorong keinginan anak untuk belajar seperti menyediakan mainan untuk belajar warna, bentuk, ukuran; tidak disediakan mainan yang menantang; kurang tersedianya mainan bebas berekspresi (seperti spidol, crayon, cat air); dan juga anak tidak memiliki mainan untuk belajar lewat media audio/visual yang lebih beragam. Selain itu, kebiasaan membaca dalam keluarga baik dalam bentuk koran, buku, maupun majalah juga masih rendah.

Tabel 3. Sebaran anak contoh menurut ratarata pencapaian skor subskala HOME Inventory usia 3-5 tahun

\begin{tabular}{|c|c|}
\hline Subskala & Rata-rata \pm SD \\
\hline Stimulasi belajar & $23,0 \pm 23,2$ \\
\hline Stimulasi bahasa & $87,3 \pm 15,9$ \\
\hline Lingkungan fisik & $57,6 \pm 22,2$ \\
\hline Kehangatan dan penerimaan & $67,6 \pm 30,1$ \\
\hline Stimulasi akademik & $68,9 \pm 30,3$ \\
\hline Modelling & $57,6 \pm 20,6$ \\
\hline Variasi stimulasi kepada anak & $48,7 \pm 16,9$ \\
\hline Hukuman & $86,8 \pm 19,4$ \\
\hline$\%$ Rata-rata keseluruhan subskala & $57,4 \pm 13,1$ \\
\hline
\end{tabular}


Hasil yang tersaji pada Tabel 2 dan Tabel 3 menunjukkan bahwa anak contoh, baik pada anak usia $\leq 3$ tahun maupun $>3$ tahun, kurang memperoleh stimulasi yang terkait dengan penyediaan media belajar di rumah. Kondisi ini mungkin terjadi karena keterbatasan ekonomi dan juga pengetahuan dari para orangtua, yang notabene merupakan orangtua dengan pendidikan rendah dan tingkat pendapatan yang terbatas.

\section{Perkembangan Kognitif}

Perkembangan kognitif dalam penelitian ini dibagi ke dalam tiga kategori usia. Kategori tersebut yaitu anak usia 2-3 tahun, 3-4 tahun, dan 4-5 tahun.

Anak usia 2-3 tahun. Pada kelompok usia ini, lebih dari separuh contoh $(54,5 \%)$ memiliki perkembangan kognitif dalam kategori rendah (Gambar 1). Hal ini terjadi terkait dengan stimulasi psikososial yang diberikan masih belum optimal. Seperti pembahasan sebelumnya, untuk kelompok anak usia <3 tahun, skor terendah dalam stimulasi psikososial adalah penyediaan mainan. Rendahnya penyediaan mainan oleh orangtua kemungkinan akan menyebabkan stimulasi kognitif yang terbatas. Keadaan inilah yang berkaitan erat dengan rendahnya perkembangan kognitif anak contoh usia 2-3 tahun. Oleh karenanya diperlukan keterlibatan ibu dalam mendidik anak, sehingga anak akan merasa nyaman dan aman dengan lingkungan sekitar yang akan berdampak pada perkembangan anak terutama perkembangan kognitif.

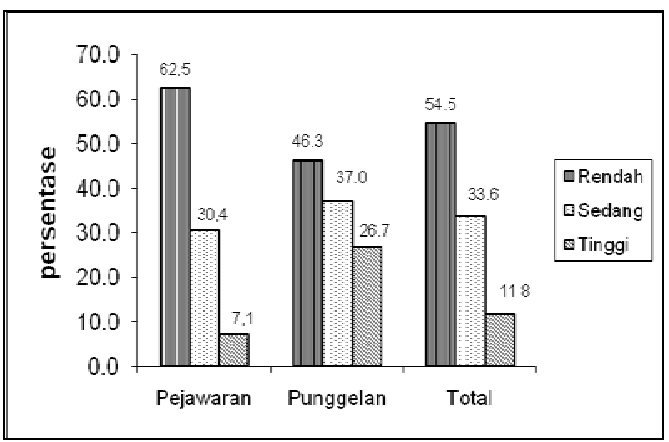

Gambar 1. Sebaran anak contoh usia 2-3 tahun menurut kategori perkembangan kognitif
Anak usia 3-4 tahun. Sementara itu, tujuh dari sepuluh anak contoh $(69,3 \%)$ usia 3-4 tahun juga memiliki perkembangan kognitif pada kategori rendah (Gambar 2). Hal ini juga mengindikasikan bahwa rendahnya perkembangan kognitif dikarenakan oleh rendahnya stimulasi yang diberikan orangtua kepada anak dalam proses pengasuhannya. Disamping itu, rendahnya perkembangan kognitif anak menunjukkan belum maksimalnya stimulasi-stimulasi yang diberikan sehingga perkembangannya belum optimal. Hal ini diperkuat dengan temuan masih rendahnya stimulasi psikososial anak usia 3-4 tahun, yang berada di dalam rentang usia 3-5 tahun (Tabel 3), yang telah dibahas sebelumnya.

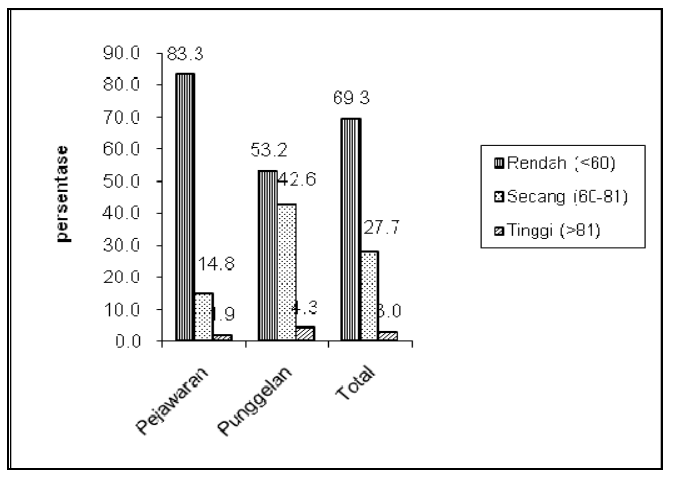

Gambar 2. Sebaran anak usia 3-4 tahun berdasarkan kategori perkembangan kognitif

Anak usia 4-5 tahun. Capaian perkembangan kognitif yang masih rendah juga ditemukan pada kelompok usia 4-5 tahun. Berdasarkan sebarannya, lebih dari separuh anak contoh usia 4-5 tahun $(60,7 \%)$ memiliki perkembangan kognitif yang termasuk ke dalam kategori rendah. Hal ini memperlihatkan bahwa optimalisasi perkembangan kognitif belum juga dilakukan oleh orangtua pada anak kelompok usia 4-5 tahun. Temuan ini diperkuat oleh temuan tentang rataan stimulasi psikososial pada kelompok anak usia 3-5 tahun, dimana pada stimulasi belajar hanya mencapai skor rataan 23,00 . Begitu juga pada variasi stimulasi yang hanya mencapai rataan 48,7 yang juga menunjukkan pemberian stimulasi kognitif yang masih rendah (Tabel 3). 


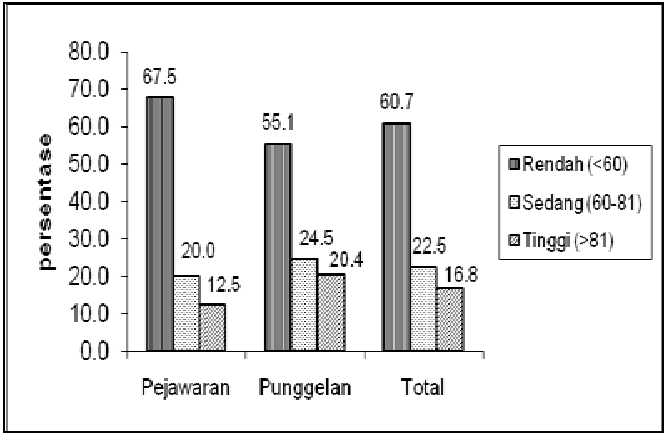

Gambar 3. Sebaran anak usia 4-5 tahun berdasarkan kategori perkembangan kognitif

\section{Faktor-Faktor yang Berhubungan dengan Perkembangan Kognitif}

Analisa terhadap faktor-faktor yang berhubungan dengan perkembangan kognitif dilakukan dalam penelitian ini untuk dapat diketahui faktor-faktor yang secara signifikan berhubungan dengan perkembangan kognitif anak contoh. Hasil penelitian ini menunjukkan adanya hubungan antara stimulasi psikososial $(r=0,391 ; p$-value $=0,000)$, pendidikan ibu $(r=0,290 ; p$-value $=0,000)$, partisipasi pendidikan prasekolah anak $(r=0,227 ; p$-value $=0,000)$, dan nilai anak $(r=0,149 ; \quad p$-value $=0,010)$ dengan perkembangan kognitif. Temuan ini berarti bahwa anak yang orangtuanya memberikan stimulasi psikososial yang optimal, memiliki tingkat pendidikan yang tinggi, dan memiliki persepsi yang positif terhadap anak, anak usia 2-5 tahunnya akan memiliki perkembangan kognitif yang baik dan optimal. Sementara itu, anak usia 2-5 tahun yang mengikuti pendidikan prasekolah juga akan memiliki perkembangan kognitif yang tinggi dibandingkan dengan anak yang tidak mengikuti pendidikan prasekolah.

Hasil penelitian ini menegaskan bahwa pemberian stimulasi psikososial yang optimal kepada anak akan meningkatkan perkembangan kognitif anak. Pernyataan ini sejalan dengan penelitian Mindasa (2007),
Rahmaulina (2007), serta Hastuti dan Alfiasari (2008) yang melaporkan bahwa stimulasi psikososial berpengaruh terhadap perkembangan kognitif anak.

\section{Faktor-Faktor yang Mempengaruhi Perkembangan Kognitif}

Hasil analisa regresi yang diuji dalam penelitian ini melalui model yang telah disusun (Tabel 4), memperlihatkan bahwa perkembangan kognitif anak ditentukan oleh stimulasi psikososial $(\beta=0,512)$, dimana kenaikan satu satuan stimulasi psikosial akan meningkatkan perkembangan kognitif sebesar 0,512 poin. Demikian pula dengan pendidikan ibu, dimana kenaikan satu tahun pendidikan ibu akan menaikkan perkembangan kognitif sebesar 1,244 poin $(\beta=1,244)$.

Hasil lain juga menunjukkan bahwa kenaikan partisipasi pendidikan prasekolah anak satu bulan akan meningkatkan perkembangan kognitif sebesar 5,382 poin $(\beta=5,382)$. Sementara itu, temuan lain dalam penelitian ini menunjukkan bahwa faktor usia anak juga mempengaruhi perkembangan kognitif, dimana anak bertambah usia satu bulan maka akan menurunkan perkembangan kognitifnya sebesar 0,301 poin $(\beta=-0,301)$. Menurunnya perkembangan kognitif yang dipengaruhi oleh bertambahnya usia anak, kemungkinan terjadi karena usia 2-5 tahun merupakan masa-masa penting dalam memberikan pendidikan usia dini untuk perkembangan kognitifnya. Sedangkan, pendidikan prasekolah yang diikuti umumnya untuk anak usia 4 tahun, sehingga anak kurang mengenal dengan pembelajaran di sekolah. Hal tersebut yang menyebabkan usia anak berpengaruh negatif terhadap perkembangan kognitif anak. Model ini menjelaskan bahwa perkembangan kognitif dapat diterangkan sebesar $19,6 \%$ melalui faktor-faktor seperti yang tersaji pada Tabel 4, dan masih banyak faktor lainnya yang menentukan perkembangan kognitif seorang anak yang tidak dilihat dalam penelitian ini. 
Tabel 4. Hasil uji regresi linear variabel yang mempengaruhi tingkat perkembangan kognitif

\begin{tabular}{|c|c|c|c|c|c|c|}
\hline & \multirow[t]{2}{*}{ Model } & \multicolumn{2}{|c|}{$\begin{array}{l}\text { Unstandardized } \\
\text { Coefficients }\end{array}$} & \multirow{2}{*}{$\begin{array}{c}\text { Standardized } \\
\text { Coefficients } \\
\text { Beta }\end{array}$} & \multirow[t]{2}{*}{ t } & \multirow[t]{2}{*}{ Sig. } \\
\hline & & B & Std. Error & & & \\
\hline \multirow[t]{10}{*}{1} & (Constant) & 17,206 & 9,983 & & 1,724 & 0,086 \\
\hline & Úsia ibu & 0,162 & 0,190 & 0,047 & 0,853 & 0,394 \\
\hline & Besar keluarga & 0,363 & 0,921 & 0,022 & 0,394 & 0,694 \\
\hline & Pendidikan ibu & 1,244 & 0,567 & 0,131 & 2,194 & 0,029 \\
\hline & Pengeluaran (Rp/kap/bul) & $4,13 \mathrm{E}-005$ & 0,000 & 0,140 & 2,384 & 0,018 \\
\hline & Jenis kelamin & $-0,823$ & 2,479 & $-0,017$ & $-0,332$ & 0,740 \\
\hline & Usia anak & $-0,301$ & 0,133 & $-0,131$ & $-2,265$ & 0,024 \\
\hline & Partisipasi pendidikan prasekolah & 5,382 & 1,880 & 0,161 & 2,863 & 0,005 \\
\hline & Stimulasi psikososial & 0,512 & 0,118 & 0,286 & 4,343 & 0,000 \\
\hline & $\begin{array}{lll}\text { Keterangan: } & * & =p<0,05 \\
& * * & =p<0,005 \\
& * * * & =p<0,001\end{array}$ & & & & & \\
\hline
\end{tabular}

\section{KESIMPULAN DAN SARAN}

\section{Kesimpulan}

Stimulasi psikososial anak usia 2-3 tahun jika dilihat dari sebarannya, termasuk ke dalam kategori rendah $(85,5 \%)$. Selain itu, $57,1 \%$ anak mendapatkan stimulasi psikososial dalam kategori rendah. Secara umum, perkembangan kognitif anak termasuk ke dalam kategori rendah.

Terdapat hubungan yang nyata dan positif antara nilai anak dengan stimulasi psikososial anak di lokasi penelitian. Artinya bahwa semakin tinggi nilai anak semakin tinggi stimulasi psikososial yang diberikan. Demikian pula antara stimulasi psikososial dan perkembangan kognitif. Terdapat hubungan yang nyata dan positif antara stimulasi psikososial dan perkembangan kognitif. Artinya bahwa semakin tinggi stimulasi psikososial yang diberikan, semakin tinggi perkembangan kognitif anak.

Hasil uji regresi menunjukkan bahwa ada pengaruh yang positif dan signifikan antara lama pendidikan ibu (tahun), lama pendidikan prasekolah anak (bulan), pengeluaran per kapita per bulan dan stimulasi psikososial. Hasil uji menunjukkan bahwa usia anak berpengaruh negatif terhadap perkembangan kognitif. Hal ini menunjukkan adanya kecenderungan adanya penurunan perkembangan kognitif seiring dengan bertambahnya usia.

\section{Saran}

Adanya pengaruh yang signifikan antara lama pendidikan prasekolah anak dengan perkembangan kognitif, maka disarankan agar keluarga yang memiliki anak usia 2-5 tahun untuk mengikutkan anaknya pada pendidikan prasekolah. Disamping itu, untuk
Dinas Pendidikan setempat disarankan untuk melakukan sosialisasi kepada keluarga mengenai pentingnya keikutsertaan anak dalam pendidikan prasekolah. Hal serupa juga ditujukan kepada Posyandu yang berintegrasi dengan Kelompok PAUD untuk menyebarluaskan dan menginformasikan kepada keluarga mengenai pentingnya anak mengikuti pendidikan prasekolah dengan menyebarkan leaflet, mengunjungi ke rumahrumah keluarga dan menjadikan agenda rutin setiap bulan dalam Posyandu.

Selain itu, mengingat stimulasi psikososial berpengaruh terhadap perkembangan kognitif anak maka disarankan kepada keluarga untuk memberikan stimulasi yang maksimal kepada anak. Jika dalam pemberian stimulasi terbentur oleh dana disarankan untuk meningkatkan aktivitas ibu dan anak, ibu lebih terlibat dalam pengasuhan (bermain bersama anak, pergi bersama anak), serta memberikan kehangatan dan penerimaan kepada anak serta memberikan teladan kepada anak. Hal ini mengindikasikan pentingnya pendidikan parenting untuk ibu mengenai bagaimana memberikan stimulasi kepada anak yang dapat dilakukan oleh koordinasi tim penggerak PKK dan Kelompok PAUD. Selain itu, perlu adanya penelitian lanjutan berupa observasi yang mendalam untuk mendapatkan data pengukuran pengasuhan yang berlangsung di pedesaan dan untuk melihat nilai-nilai apa yang berlaku. Oleh karena itu disarankan adanya penyesuaian-penyesuaian yang dilakukan baik pada kuesioner maupun pada alat bantu perkembangan kognitif untuk disesuaikan dengan wilayah setempat/tempat penelitian. 


\section{DAFTAR PUSTAKA}

Anwar F. 2002. Model Pengasuhan Anak Bawah Dua Tahun Dalam Meningkatkan Status Gizi dan Perkembangan Sosial [tesis]. Bogor. Sekolah Pascasarjana. Institut Pertanian Bogor.

Brooks JB. 2001. Parenting. United State of America: Mayfiled Publishing Company.

Dariyo A. 2007. Psikologi Perkembangan Anak Tiga Tahun Pertama. Bandung: PT Refika Aditama.

Hastuti D. 2006. Analisis Pengaruh Model Pendidikan Prasekolah pada Pembentukkan Anak Sehat, Cerdas, dan Berkarakter [disertasi]. Bogor. Sekolah Pascasarjana. Institut Pertanian Bogor.

Hastuti D, Alfiasari. 2008. Stimulasi Psikososial dan Pengaruhnya pada Karakter Anak yang Bersekolah dan Tidak Bersekolah di Taman Bermain Semai Benih Bangsa, Kabupaten Aceh Utara, Provinsi NAD. Jurnal IImu Keluarga dan Konsumen 1:141-152.
Hernawati N. 2002. Nilai Anak dan Pengasuhan Berdasarkan Gender pada Anak Usia 2-3 Tahun di Kota Bogor [skripsi]. Bogor. Fakultas Pertanian. Institut Pertanian Bogor.

Khomsan A. 2002. Peranan Pangan dan Gizi untuk Kualitas Hidup. Jakarta: PT Gramedia.

Mindasa. 2007. Pengaruh Pemberian ASI dan Stimulasi Psikososial terhadap Tingkat Perkembangan Kognitif Anak Usia 2,5-5 Tahun [skripsi]. Bogor. Fakultas Pertanian. Institut Pertanian Bogor.

Rahmaulina N. 2007. Hubungan Pengetahuan Ibu tentang Gizi dan Tumbuh Kembang Anak serta Stimulasi Psikososial dengan Perkembangan Kognitif Anak Usia 2,5-5 Tahun [skripsi]. Bogor. Fakultas Pertanian. Institut Pertanian Bogor.

Sununingsih D. 2006. Membentuk Kecerdasan Anak Sejak Dini. Yogyakarta: Penerbit Think.

*Korespondensi :

Telp : +62-251 8628303

Email: tutimartianto@yahoo.com 